\title{
Native forage quality, quantity, and profitability as affected by fertilization in northern Mexico
}

\author{
H. O. RUBIO, M. K. WOOD, A. GOMEZ, AND G. REYES
}

\begin{abstract}
Authors are researcher, La Campana Experimental Station, INIFAP-MEXICO; professor, Dept. of Animal and Range Sciences, New Mexico State University; and researchers, La Campana Experinental Station, INIFAP-MEXICO, respectively.
\end{abstract}

\begin{abstract}
Fourteen treatments of nitrogen $(\mathrm{N})$ and phosphorus $(\mathrm{P})$ fertilizers were applied in an overgrazed ejido rangeland in northern Mexico, during 1990 and 1991. Eight treatments were applied using ammonium nitrate as a source of $N(60-0-0,60-30-0,60-60-0$, 80-40-0, 120-30-0, 120-60-0, 120-90-0 and 180-60-0 $\left.\mathrm{kg} \mathrm{ha}^{-1}\right), 2$ treatments with ammonium sulfate $\left(60-30-0\right.$ and $\left.120-60-0 \mathrm{~kg} \mathrm{ha}^{-1}\right)$, 2 with urea $\left(60-30-0\right.$ and $\left.120-60-0 \mathrm{~kg} \mathrm{ha}^{-1}\right)$, only $P\left(0-30-0 \mathrm{~kg} \mathrm{ha}^{-1}\right)$, and the control $\left(0-0-0 \mathrm{~kg} \mathrm{ha}^{-1}\right)$. Triple superphosphate was applied as a source for $P$. The 80-40-0 treatment was included because it was the commonly recommended rate for the area. Fertilizers were applied at the beginning of the rainfall season (July) and forage was harvested in late October (1990) and mid-November (1991). Dry matter production, crude protein (CP) content, and in situ digestibility were determined. An economic analysis was used to obtain the best economic treatment for forage production. In 1990 with a precipitation of $377 \mathrm{~mm}$, dry matter production was significantly affected for both source and rate of $N$. The maximum amount of dry matter was obtained with a rate of 120 90-0 kg ha-1 using ammonium nitrate. However, the best treatment in terms of economic return was $120-30-0 \mathrm{~kg} \mathrm{ha}^{-1}$ as ammonium nitrate. Urea did not produce as well as other $\mathrm{N}$ source treatments. Crude protein was highest in treatments with the higher $\mathbf{N}$, but no significant trend was evident. In situ digestibility was not affected by rate or source of N fertilizer. During 1991, precipitation was higher than in 1990. Significant differences were determined among $\mathbf{N}$ rates but not in $\mathbf{N}$ source. In fact, urea produced greater in dry matter production than other $\mathrm{N}$ sources at the same rate. The maximum amount of dry matter was obtained with the 180-60-0 treatment using ammonium nitrate with $4,190 \mathrm{~kg} \mathrm{ha}^{-1}$, but the best economic treatments were the $120-30-0$ and $60-0-0$ with a marginal return rate of $377 \%$ and $355 \%$, respectively. Results of $\mathrm{CP}$ and in situ digestibility were similar to those of 1990.
\end{abstract}

Key Words: crude protein, rangeland, phytomass production, in situ digestibility, ammonium nitrate, ammonium sulfate, urea, economic benefits

Mexico has 92 million hectares of rangeland, many of which have deteriorated due to intensive livestock grazing. Application

The authors wish to thank Alicia Melgoza, Mario Royo, Edmundo Nava, the Ejido Basuchil, and Distrito de Desarrollo Rural de Papigochi, Gucrero for helping in this research. Article published under direction of the New Mexico State University Agricultural Experiment Station.

Manuscript accepted 8 Sept. 1996. of inorganic fertilizer may help improve some of these areas. Even though this practice has demonstrated a potential to significantly increase both amount and quality of forage around the world, it is not yet widely applied in Mexico. The primary reason is that the price of fertilizer is high or changes frequently. A second reason is that many rangelands experience high climatic variability every year that affects the results of this practice. These reasons represent high risks to the ranchers. It is believed that in general, the response of rangeland to applied fertilizer depends on 1) kind of fertilizer, 2) rates and application method, 3) density and type of vegetation, 4) soil type and soil fertility, and 5) abiotic factors such as evaporation and precipitation.

The effect of applying inorganic fertilizers to increase forage production on rangeland in the USA has been the focus of several studies (Power and Alessi 1971; Black and Wight 1979; and Wood et al. 1986). Nevertheless, there are few studies on fertilization of Mexico's rangelands. Ojeda (1969) in a study in the north of Mexico reported significantly greater forage production with application of $120 \mathrm{~kg}$ of nitrogen (N) per hectare in shortgrass than in areas with no fertilizer; he noted that the residual effect could be beneficial for at least 4 years. Sanchez (1972) hypothesized a linear relationship of forage production and protein content as the rate of $\mathrm{N}$ and phosphorus (P) was increased. $\mathrm{He}$ also found that the best application was $80-25-0 \mathrm{~kg} \mathrm{ha}^{-1}$. Gonzalez (1972) suggested that application of $80 \mathrm{~kg} \mathrm{ha}^{-1}$ of ammonium nitrate and $25 \mathrm{~kg} \mathrm{ha}^{-1}$ of phosphorus pentoxide $\left(\mathrm{P}_{2} \mathrm{O}_{5}\right)$ increased forage production $132 \%$ in a shortgrass community dominated by blue grama (Bouteloua gracilis [Willd ex H.B.K.] Lag. ex. Griffiths) and wolftail (Lycurus phleoides H.B.K.). He also noted that protein and phosphorus content were significantly increased with this treatment. Sosa (1983) showed that the highest forage production was with application of $200 \mathrm{~kg}$ of nitrogen per hectare.

The state of Chihuahua, located in the north of Mexico, has about 17 million hectares of rangeland. In general, like most arid and semi-arid range areas, the precipitation is erratic and infrequent. However, there are approximately 3 million hectares with good plant cover with an average precipitation of more than 500 $\mathrm{mm}$ per year distributed from June to October. The rehabilitation of this area may be accelerated with applications of inorganic fertilizers. But very little is known about the effects of fertilizer applications on forage production and quality of that forage in an overgrazed area in Mexico. Therefore, the objective of this research was to determine if differences in forage production exist when applying different sources of fertilizers as well as dif- 
ferent rates on deteriorated shortgrass rangeland in the State of Chihuahua, Mexico. The second objective was to examine the protein content and in situ digestibility of the produced forage. A third objective was to determine net economic benefits. This research may lead to a better understanding of the rolc of nitrogen and phosphorus in a native grassland of Northern Mexico.

\section{Materials and Methods}

Two field trials were conducted during the summers of 1990 and 1991 on the Ejido Basuchil in the state of Chihuahua. An "Ejido" is a community where the law establishes that any timber or grazing lands must be used collectively or shared (Cornehls, 1964). This has caused most Ejido rangeland areas to presently be in poor condition. Basuchil is representative of a deteriorated grassland that is grazed mainly by domestic livestock, and a number of low quality horses that consume more forage than the cattle and produce little economic value.

Records of 16 years of precipitation in the area show that mean annual precipitation was $534 \mathrm{~mm}$. Precipitation during 6 years was above the mean, and precipitation for 10 years was below the mean with all being higher than $400 \mathrm{~mm}$ yearly except for 1979 (Fig. 1). Most of the growing season precipitation came during June to October, and fluctuations of wet and dry years are not as dynamic as on other sites in the state. Some snow events occur during the winter. During the study, July to October precipitation was recorded using a rain gauge that was placed beside the experimental plots.

Soil samples were taken between $0-15,15-30$, and $30-60 \mathrm{~cm}$ each indicated a pH of 6.1 ; organic matter $0.93 \%$; nitrogen $0.08 \%$ (based on organic matter content); available phosphorus $9.7 \mathrm{ppm}$; available potassium $560 \mathrm{~kg} \mathrm{ha}^{-1}$; and electrical conductivity of $0.24 \mathrm{dS} \mathrm{m}^{-1}$. The soil is a fine-loamy, mixed, mesic, Aridic
Paleustoll. The dominant species were zacate navajita azul (blue grama), setaria (bristlegrass) (Setaria spp. Beauv.), lobero (wolftail), microcloa (Microchloa kuntii Desv.), and tres barbas (three awns) (Aristida spp. L.). Other species were junco (flatsedge) (Cyperus spp. L.), liendrilla morada (muhly) (Muhlenbergia spp. Schreb.), and navajita velluda (hairy grama) (Bouteloua hirsuta Lag.).

Fertilizer treatments were applied by hand in a single application in the first week of July of 1990 and 1991 before the first growing season precipitation event occurred. Each treatment plot was $100 \mathrm{~m}^{2}(10 \mathrm{~m} \times 10 \mathrm{~m})$ with a distance between plots of one meter. After fertilizer applications, the experimental areas were excluded from grazing.

The 3 nitrogen sources were ammonium nitrate $(33.55 \% \mathrm{~N})$, ammonium sulfate $(20.5 \%)$, and urea (45\%). Phosphorus was applied as triple superphosphate (46\% P205). The treatments using ammonium nitrate were selected as a result of an incomplete factorial: $60-0-0,60-30-0,60-60-0,120-30-0,120-60-0$, 120-90-0, and 180-60-0. Treatments with ammonium sulfate were 60-30-0 and 120-60-0 and treatments with urea were 60-300 and 120-60-0. In addition, we included a treatment $80-40-0$ as a local control (personal communication with FERTMEXX found that this rate was commonly used), a treatment with only triple superphosphate $0-30-0$, and a control 0-0-0. These 14 treatments were placed in a randomized complete block design with 4 replications.

The data for experiment 1990 were collected once in late October and data of experiment 1991 were collected in midNovember. To evaluate forage production, a 0.25 by $1 \mathrm{~m}$ rectangular quadrat was used. Three quadrats selected at random were handclipped at ground level in each treatment plot. Dry matter yield was determined after oven drying the samples at $60^{\circ} \mathrm{C}$. An analysis of variance was conducted, and orthogonal contrasts were utilized to check for treatment differences at the 0.05 level of significance.

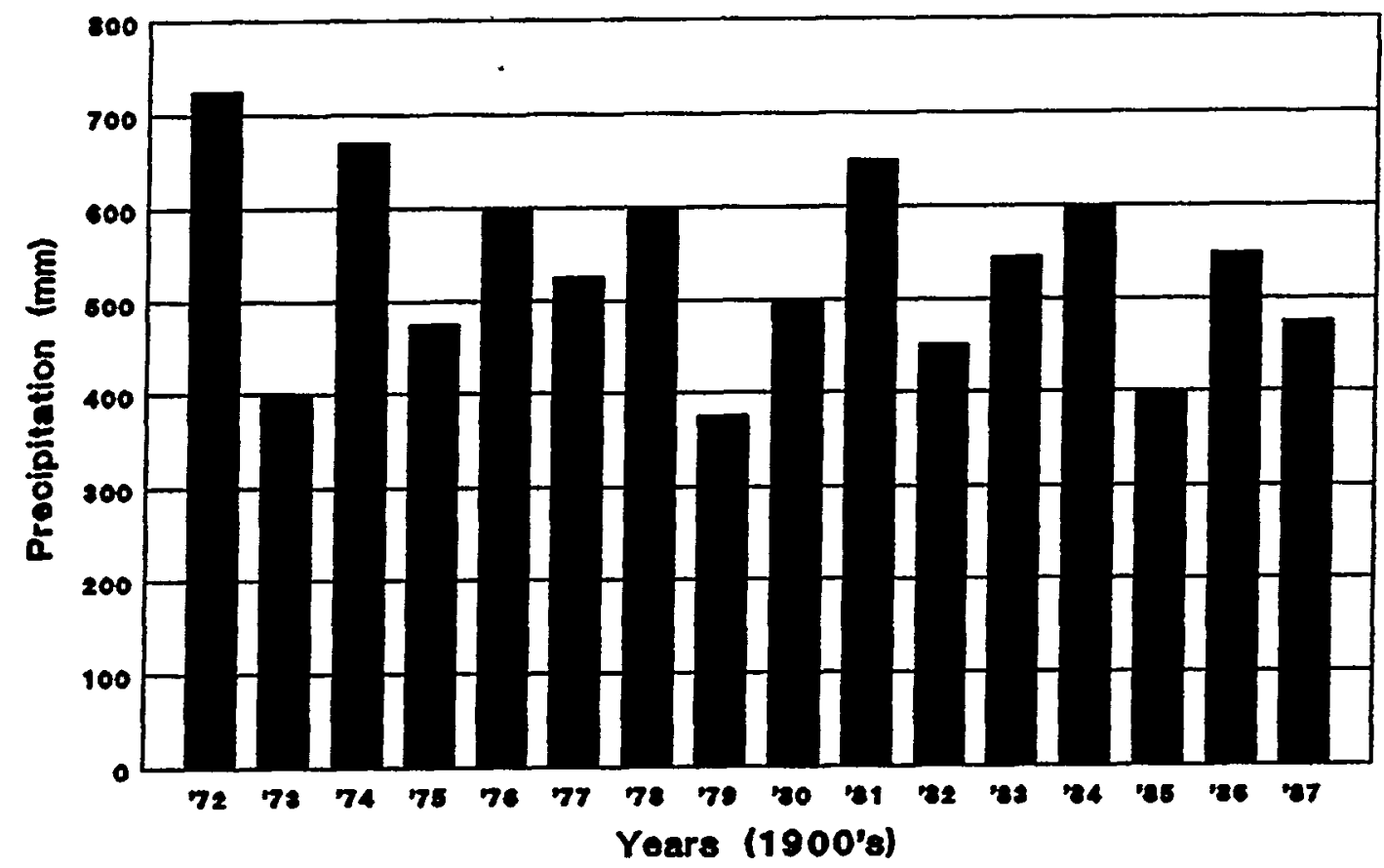

Fig. 1. Mean long-term precipitation (mm) at Basuchil, Chihuahua, Mexico. 
Precipitation-use efficiency was determined by dividing forage yield over total precipitation of the growing season. An economic analysis was conducted using the following prices for the fertilizer (per metric ton); urea $\$ 120.86$ (392,808 pesos), ammonium nitrate $\$ 101.17$ (328,808 pesos), ammonium sulfate $\$ 72.81$ (236,640 pesos), and triple superphosphate $\$ 154.54(502,246$ pesos). This economic analysis was conducted according to the method suggested by Perrin et al. (1988). This economic analysis compares the costs that vary with the net benefits. This comparison is important to farmers because they are interested in seeing the increase in costs required to obtain a given increase in net benefits. The net benefit curve is useful for visualizing the changes in costs and benefits in passing from one treatment to the treatment of next highest cost. The net benefit curve also clarifies the reasoning behind the calculation of marginal rates of return, which compare the increments in costs and benefits between such pairs of treatments. Values below the line have higher costs that vary, but lower net benefits than values on the line. These values below the line represent dominated treatments and are eliminated from consideration.

Crude protein (CP) was determined using three samples for treatment by micro-Kjeldahl (Tejada 1983). To evaluate in situ digestibility, 2 rumen fistulated bulls weighing about $550 \mathrm{~kg}$ were used. One week before placing the nylon bags in the rumen, the bulls grazed in a shortgrass area dominated by zacate navajita azul (blue grama).

Crude protein and in situ digestibility were analyzed as a completely randomized design. A protected least significant difference test at the 0.01 level of significance was used as a multiple comparison technique (Dowdy and Wearden 1991).

\section{Results and Discussion}

\section{Results}

In the summer of 1990 , the first growing season precipitation event occurred on 13 July. The experimental plots received a total of $377 \mathrm{~mm}$ of rainfall during the growing season (July to October), which was slightly below normal. Dry matter production was significantly affected by source of fertilizer as well as rates (Table 1).
The maximum amount of dry matter $\left(3,810 \mathrm{~kg} \mathrm{ha}^{-1}\right)$ was obtained with ammonium nitrate (120-90-0). On the other hand, the control treatment only reached about $520 \mathrm{~kg} \mathrm{ha}^{-1}$ which was significantly lower than yields from all fertilizer treatments. In general, treatments with ammonium nitrate produced more forage than trcatments with ammonium sulfate as a source of $\mathbf{N}$ (Table 1 ). Ammonium sulfate produced more than urea.

Even though both treatments with urea significantly increased dry matter production in comparison with the control, surprisingly the treatment with $120-60-0$ did not yield more $\left(1350 \mathrm{~kg} \mathrm{ha}^{-1}\right)$ than the treatment with $60-30-0$ which produced $1434 \mathrm{~kg} \mathrm{ha}^{-1}$. Treatments with ammonium sulfate were different from treatments with urea. The treatment with $60-30-0$ produced $1,760 \mathrm{~kg}$ $\mathrm{ha}^{-1}$ whereas the treatment with $120-60-0$ yielded significantly more at $2,662 \mathrm{~kg} \mathrm{ha}^{-1}$. These results clearly confirmed that ammonium nitrate and ammonium sulfate are the best sources of inorganic fertilizers to apply on this rangeland in terms of dry matter production under the conditions given in this year.

A synergistic effect was noted during 1990 with $\mathrm{N}$ and $\mathrm{P}$. The treatment with triple superphosphate alone (0-30-0) was the same as the control (Table 1). Nitrogen alone (60-0-0) yielded $1,280 \mathrm{~kg}$ $\mathrm{ha}^{-1}$, but when both $\mathrm{N}$ and $\mathrm{P}$ were applied, $696 \mathrm{~kg} \mathrm{ha}^{-1}$ more forage was harvested. This obviously exceeded the sum of the individual responses. This result of synergism agrees with the findings of Wight and Black (1979) who found that $N$ alone or $P$ alone yielded less than application of both elements together on glaciated plains of eastern Montana.

Precipitation-use efficiency was higher in treatments with ammonium nitrate and ammonium sulfate, whereas the treatment with 120-90-0 obtained $10 \mathrm{~kg} \mathrm{ha}^{-1}-\mathrm{mm}$ in comparison with $1.3 \mathrm{~kg}$ $\mathrm{ha}^{-1}-\mathrm{mm}$ in the control. Urea only improved soil water-use efficiency compared with the control treatment and also with respect to the treatments with $0-30-0$ and $60-0-0$ among nitrate treatments.

Crude protein was significantly different among treatments during 1990 (Table 1). Crude protein content was higher in treatments with the highest $\mathrm{N}$ than in other treatments. Treatments with $120-90-0$ and $180-60-0$ reached $6.9 \%$ and $6.8 \%$ crude protein, respectively, while the control gave $5.0 \%$. However, crude protein content varied considerably, but no specific trend was

Table 1. Forage production, crude protein, in situ digestibility, and precipitation use efficiency on a rangeland with different fertilization treatments during 1990 and 1991.

\begin{tabular}{|c|c|c|c|c|c|c|c|c|c|c|c|}
\hline \multirow[b]{2}{*}{$\begin{array}{l}\text { Fertilizer } \\
\text { treatments } \\
\text { N-P-K }\end{array}$} & \multicolumn{5}{|c|}{ Year 1990} & \multicolumn{6}{|c|}{ Year 1991} \\
\hline & $\begin{array}{l}\text { Fertilizer } \\
\text { sources }\end{array}$ & Yield & $\begin{array}{l}\text { Crude } \\
\text { protein }\end{array}$ & $\begin{array}{c}\text { In situ } \\
\text { digestibility }\end{array}$ & $\begin{array}{l}\text { Precipitation } \\
\text { use } \\
\text { efficiency }\end{array}$ & $\begin{array}{l}\text { Fertilizer } \\
\text { treatments }\end{array}$ & $\begin{array}{l}\text { Fertilizer } \\
\text { sources }\end{array}$ & Yield & $\begin{array}{l}\text { Crude } \\
\text { protein }\end{array}$ & $\begin{array}{c}\text { In situ } \\
\text { digestibility }\end{array}$ & $\begin{array}{l}\text { Precipitation } \\
\text { use } \\
y \text { efficiencey }\end{array}$ \\
\hline & & $\left(\mathrm{kg} \mathrm{ha}^{-1}\right)$ & $(\%)$ & $(\%)$ & $\left(\mathrm{kg} \mathrm{mm}^{-1}\right)$ & & & $\left(\mathrm{kg} \mathrm{ha}^{-1}\right)$ & $(\%)$ & $(\%)$ & $\overline{\left(\mathrm{kgmm}^{-1}\right)}$ \\
\hline $120-90-0$ & Nitrate & 3810 & $6.9 \mathrm{a}$ & 60 & 10.0 & $180-60-0$ & Nitrate & 4190 & $6.7 \mathrm{ab}$ & 60 & 7.6 \\
\hline $180-60-0$ & Nitrate & 3502 & $6.8 \mathrm{a}$ & 60 & 9.2 & $120-30-0$ & Nitrate & 4065 & $5.7 \mathrm{~d}$ & 60 & 7.4 \\
\hline $120-60-0$ & Sulfate & 2662 & $6.3 \mathrm{~b}$ & 60 & 7.0 & $120-60-0$ & Urea & 4000 & $6.1 \mathrm{c}$ & 60 & 7.3 \\
\hline $120-30-0$ & Nitrate & 2528 & $5.9 \mathrm{c}$ & 58 & 6.7 & $120-60-0$ & Nitrate & 3865 & $6.5 \mathrm{~b}$ & 58 & 7.0 \\
\hline $120-60-0$ & Nitrate & 2441 & $6.2 \mathrm{bc}$ & 58 & 6.4 & $120-60-0$ & Sulfate & 3500 & $6.6 \mathrm{ab}$ & 58 & 6.3 \\
\hline $60-30-0$ & Nitrate & 1980 & $5.1 \mathrm{ef}$ & 58 & 5.2 & $120-90-0$ & Nitrate & 3260 & $7.0 \mathrm{a}$ & 58 & 5.9 \\
\hline $80-40-0$ & Nitrate & 1971 & $6.2 \mathrm{bc}$ & 50 & 5.2 & $80-40-0$ & Nitrate & 2865 & $6.4 \mathrm{bc}$ & 50 & 5.2 \\
\hline $60-30-0$ & Sulfate & 1760 & $5.5 \mathrm{~d}$ & 50 & 4.6 & $60-0-0$ & Nitrate & 2035 & $5.6 \mathrm{~d}$ & 50 & 3.7 \\
\hline $60-60-0$ & Nitrate & 1717 & $4.8 \mathrm{f}$ & 50 & 4.5 & $60-30-0$ & Urea & 2025 & $5.2 \mathrm{ef}$ & 50 & 3.7 \\
\hline $60-30-0$ & Urea & 1434 & $5.1 \mathrm{ef}$ & 50 & 3.8 & $60-30-0$ & Sulfate & 1895 & $5.5 \mathrm{de}$ & 50 & 3.4 \\
\hline $120-60-0$ & Urea & 1350 & $5.2 \mathrm{de}$ & 50 & 3.5 & $60-60-0$ & Nitrate & 1560 & $5.4 \mathrm{ef}$ & 50 & 2.8 \\
\hline $60-0-0$ & Nitrate & 1286 & $5.3 \mathrm{de}$ & 50 & 3.4 & $60-30-0$ & Nitrate & 1275 & $5.5 \mathrm{de}$ & 50 & 2.3 \\
\hline $0-30-0$ & Super Triple & 613 & $5.0 \mathrm{ef}$ & 50 & 1.6 & $0-30-0$ & Super Triple & 825 & $5.0 \mathrm{f}$ & 50 & 1.8 \\
\hline $0-0-0$ & & 520 & $5.0 \mathrm{ef}$ & 50 & 1.3 & $0-0-0$ & & 810 & $5.0 \mathrm{f}$ & 50 & 1.4 \\
\hline
\end{tabular}

Means followed by the same letter for crude protein are not significantly different at the 0.05 level of probability. 
noted. In situ digestibility was not affected by fertilizer treatments. The digestibility level of the control treatment was $50 \%$ while the highest $\mathrm{N}$ treatment was similar to the control.

An economic analysis of these 1990 data shows that the best results were with ammonium nitrate as shown in the net benefit curve (Fig. 2). Values below the line have higher costs that vary, but lower net benefits than values on the line. These values below the line represent dominated treatments and are eliminated from consideration. From Figure 2, it seems reasonable that a rancher may be interested in applying the $60-0-0$ treatment although $\$ 21.54$ (70,000 pesos) $\mathrm{ha}^{-1}$ must be invested. In addition, there may be more interest in investing $\$ 30.77$ ( 100,000 pesos) ha $a^{-1}$ by selecting the 60-30-0 treatment. In this case, a net benefit of $\$ 92.31(300,000)$ pesos will be gained instead of a net benefit of less than $\$ 61.54$ (200,000 pesos) with the 60-0-0 treatment. Therefore, the results of the economic analysis show that the treatment with 60-30-0 was the best with a marginal return rate of $325 \%$. The marginal rate of return for $60-0-0$ was $107 \%, 92 \%$ for $120-30-0$, and $316 \%$ for $120-90-0$.

\section{Results}

Summer 1991 was very wet. The plot area received $547 \mathrm{~mm}$ of rainfall during the growing season. Dry matter production was not affected by the source of fertilizer but was significantly affected by rates (Table 1). The maximum amount of dry matter $\left(4,190 \mathrm{~kg} \mathrm{ha}^{-1}\right)$ was obtained with the 180-60-0 treatment while the $0-0-0$ treatment yielded $810 \mathrm{~kg} \mathrm{ha}^{-1}$. The treatment with only phosphorus (0-30-0) yielded $825 \mathrm{~kg} \mathrm{ha}^{-1}$ which was similar to the yield in the control treatment $\left(810 \mathrm{~kg} \mathrm{ha}^{-1}\right)$. This result confirms that phosphorus alone has little effect for increasing forage pro- duction. Hence, results of this research may suggest that no further research in fertilization with only phosphorus is needed. All other treatments had forage yields that were significantly greater than the control. In addition, we can not explain why the synergistic effect observed in the experiment of 1990 was not supported during the results of this year.

The results of treatments with urea during 1991 were different from the results of treatments with urea in 1990. In 1991, both increased forage production in comparison with the control (Table 1). The treatment 120-60-0 yielded $4000 \mathrm{~kg} \mathrm{ha}^{-1}$ and treatment $60-30-0$ yielded $2.025 \mathrm{~kg} \mathrm{ha}^{-1}$ while the control had $810 \mathrm{~kg}$ $\mathrm{ha}^{-1}$. The 2 treatments with ammonium sulfate were statistically different and both produced significantly more than the control. Forage production levels from nitrate, sulfate, and urea were similar in 1991. Urea at 120-60-0 produced more than all forms of 60-30-0.

During 1991, the results with respect to the percentages of crude protein were similar to those reported for 1990 . We found significant differences among treatments. The 120-90-0 treatment with ammonium nitrate reached the maximum percentage of crude protein with $7.0 \%$ in comparison with $5.0 \%$ in the control (Table 1).

In situ digestibility was not affected again either by rates or source. The 180-60-0 treatment produced $60 \%$ in comparison with $50 \%$ in the control treatment. The precipitation use efficiency was higher in all treatments than in both the control (0-0-0) and the treatment with only phosphorus (0-30-0). In general, all treatments in 1991 yielded more forage than the same treatments in 1990. It seems reasonable to assume that this result was the effect of higher precipitation.

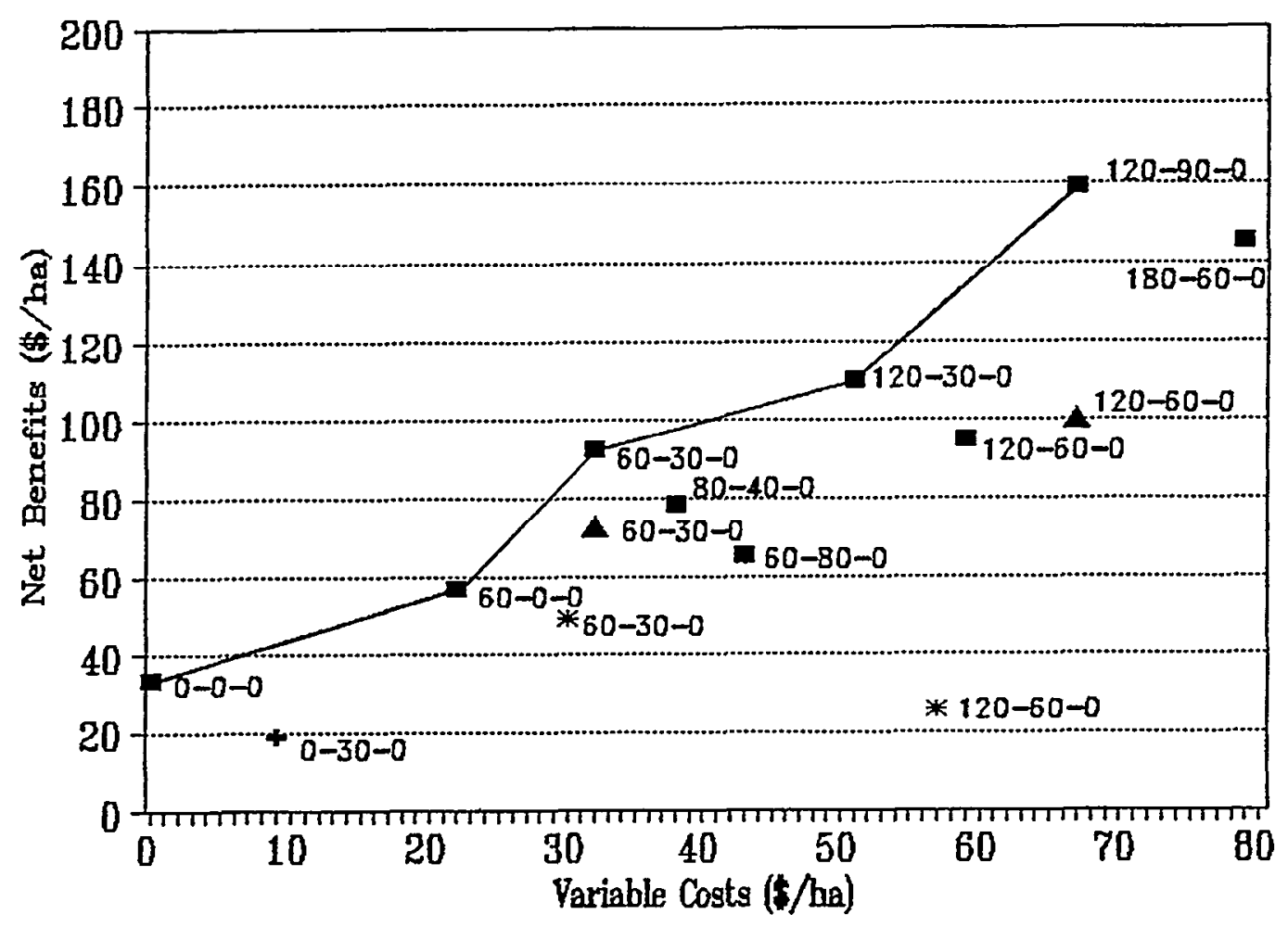

+ Phosphorus * Urea A Sulfate $\quad$ Nitrate

Fig. 2. Net benefit curve for the fertilization experiment in 1990. 


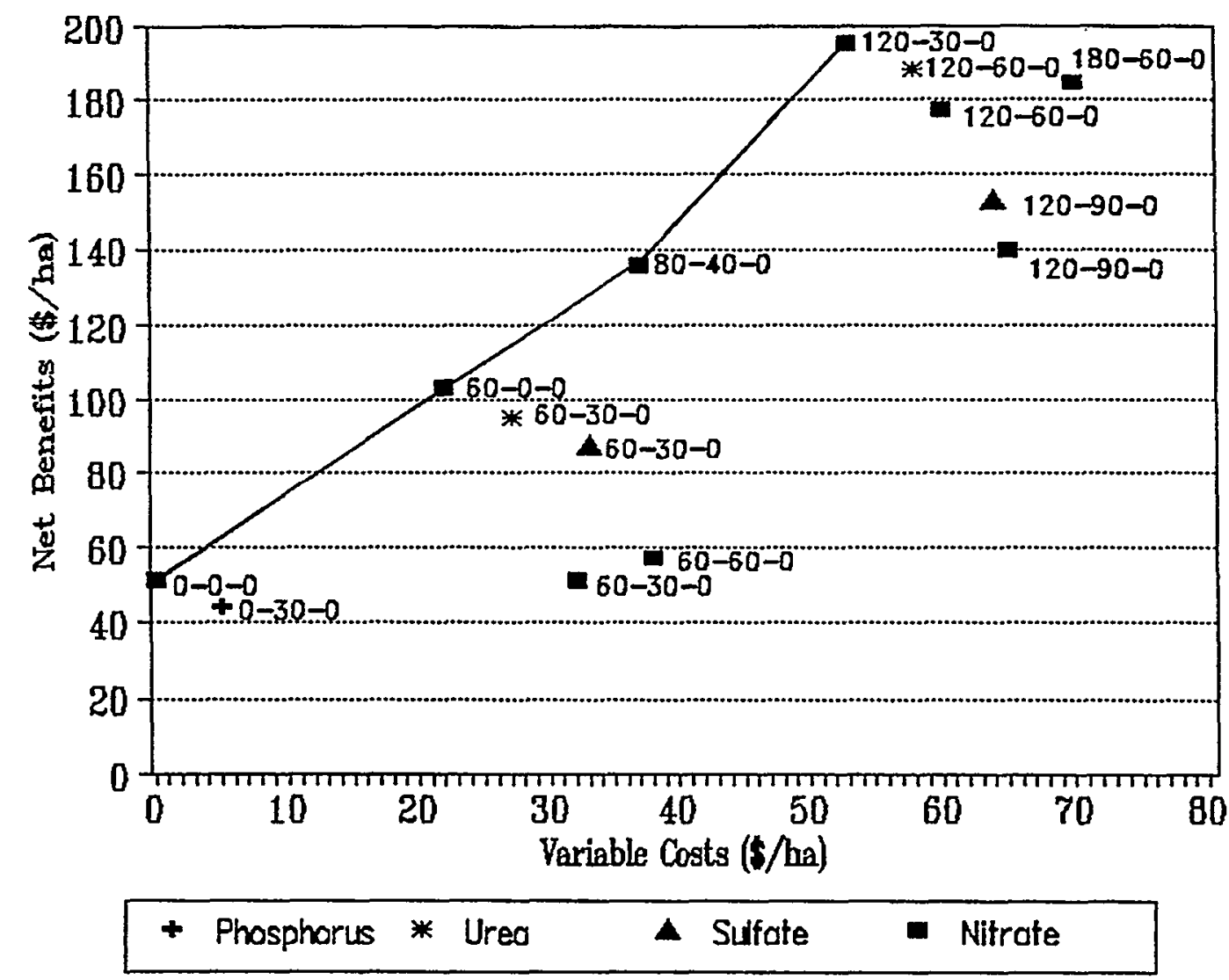

Fig. 3. Net benefit curve for the fertilization experiment in 1991.

Like 1990, an economic analysis of the 1991 data shows that the best results were with ammonium nitrate as shown in the net benefit curve (Fig. 3). Values below the line have higher costs that vary, but lower net benefits than values on the line. These values below the line represent dominated treatments and are eliminated from consideration. The marginal rate of return for $60-$ $0-0$ was $242 \%, 204 \%$ for $80-40-0$, and $377 \%$ for $120-30-0$.

\section{Conclusions}

The best sources of fertilizer to apply in this rangeland with a precipitation close to $400 \mathrm{~mm}$ are ammonium nitrate or ammonium sulfate. In addition, the 120-30-0 treatment with ammonium nitrate was the best in terms of economic return. However, with a precipitation of $500 \mathrm{~mm}$, the source of $\mathrm{N}$ fertilizer does not matter. This means that urea responds as good as other sources when more moisture is available. The practice of fertilization assures that protein content increased as well as the precipitation use efficiency.

\section{Literature Cited}

Black, A. L. and R. Wight. 1979. Range fertilization: Nitrogen and phosphorus uptake and recovery over time. J. Range Manage. 32:349-353.

Cornehls, J. V. 1964. Mexico's rural road to progress: an analysis of agrarian reform and agricultural development. Univ. of Texas, Austin.
Dowdy, S. and S. Wearden. 1991. Statistics for research. 2nd Ed. John Wiley \& Sons, New York, N.Y.

Gonzalez, M. H. 1972. Aumentos en la producción de carne con la fertilización de un pastizal. Pastizales, Vol. III.1 INIP-SAG. 2-6.

Ojeda, G. J. 1969. Respuesta de 2 tipos de pastizales a la fertilización de $\mathrm{N}$ y $\mathrm{P}$ en terminos de producción forrajera y residuo de nutrientes en el suelo y en las plantas al segundo año de su aplicación. Escuela Superior de Zootecnia, Universidad Autonoma de Chihuahua.

Perrin, R. K., D. L. Winkelmann, E. R. Moscardi, and J. R. Anderson. 1988. From agronomic data to farmer recommendations: an economics training manual. International Maize and Wheat Improvement Center (CIMMYT), Mexico City, D. F., Mexico.

Power, J. F. and J. Alessi. 1971. Nitrogen fertilization of semiarid rangeland: Plant growth and soil mineral $\mathrm{N}$ levels. Agron. J. 63:177-180.

Sanchez, B. C. 1972. Comportamiento forrajero de un pastizal mediano en la sierra de Chihuahua, bajo fertilización de nitrogeno y fosforo. Pastizales, Vol. III.1. INIP-SAG. 7-10.

Sosa, C. M. 1983. Fertilización nitrogenada a pastizales con comunidades de encino en las estribaciónes de la sierra madre occidental. Thesis. Escucla Supcrior de Zootecnia. Universidad Autonoma de Chihuahua.

Tejada, I. 1983. Manual de laboratorio para analaisis de ingredientes utilizados en la alimentación animal. Patronato de apoyo a la investigación y experimentación pecuaria en Mexico, A.C. INIP-SARH. Mexico.

Wight, R. and A. L. Black. 1979. Range fertilization: plant response and water use. J. Range Manage. 32:345-349.

Wood, M. K., G. B. Donart, and M. Weltz. 1986. Comparative infiltration rates and sediment production on fertilized and grazed blue grama rangeland. J. Range Manage. 39:371-374. 